\title{
Contribution of Human Factors to Shipping Safety
}

\author{
Arfena Deah Lestaria, Jaswara*, A. S. A. Kader ${ }^{b}$ \\ ${ }^{a}$ Department of Aeronautic, Automotive and Ocean Engineering, Faculty of Mechanical Engineering, Universiti Teknologi Malaysia, 81310 UTM Johor \\ Bahru, Johor, Malaysia \\ ${ }^{b}$ Marin Technology Center, Universiti Technologi Malaysia, 81310 UTM Johor Bahru, Johor, Malaysia \\ *Corresponding author: jaswar@fkm.utm.my and jaswar.koto@gmail.com
}

\section{Article history}

Received :15 October 2013

Received in revised form

2 November 2013

Accepted :26 November 2013

\section{Graphical abstract}

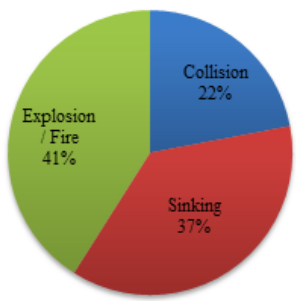

\section{Abstract}

This paper empirically determines "Contribution of Human Factors to Shipping Safety". Human factors can be classified into three categories. They are organizational factor, group factor, and individual factor Based on its classification, a questionnaire was made. A questionnaire was tested to 30 respondents who are working at a shipping company (PT. Baruna Jaya) to determine its validity and reliability by using Ms.Excel program. After the test is done, results show that 17 organizational factor statements, 11 group factor statements, 12 individual factor statements, and 10 shipping safety statements are valid with a reliability value for each variables are 0860, 0.767, 0721, and 0.8. By using its valid statements, questionnaires distributed to 86 respondents who are working as passenger ship's crew at two shipping companies (PT Baruna Jaya and PT. Lestari IndomaBahari). After obtaining data, analysis requirements test (normality, homogeneity, linearity and independence test between independent variables) needs to be done to determine the statistical method to be used. Correlation and regression method by using SPSS program was used to determine the contribution of human factors to shipping safety, either carried out independently between an independent variable to dependent variable, or together between three independent variables to the dependent variable. Analyzed data was found that there are $28.8 \%$ contribution of human factors to shipping safety with correlation coefficient is 0.488 . This lower contribution of human factors to the shipping safety is one of the causes of ship accidents frequently happen in the case study area. During the last two years there were 22 cases of ship accidents. With respect to that all parties which involve in shipping include shipping companies, the ship's owners, government, regulatory authorities, classification society and other parties should take a serious concern about safety in shipping by improving on all aspects of human factors.

Keywords: Human factors; shipping safety; correlation and regression method

(C) 2014 Penerbit UTM Press. All rights reserved.

\subsection{INTRODUCTION}

The human factors found can affect safety. 17,14,42,15,18,9,6,7,31,23, $32,10,28,13$ It can be classified as 3 categories. They are organizational, group and individual factors. At the organizational category, various factors may contribute the incidents and accidents, including company policies, company standard, and system and procedures. In the group category, management, supervision and work with relationships between members of a work group have the potential factor to influence the safety. And at the individual category, competence of the individual, perceptual judgments, stress, motivation, health risks (such as work over-load) and the contribution of human error can make a probability of accidents happen. ${ }^{43}$ However, the most significant problem which influence shipping safety that can cause accident, like collision or contact (can be ship to ship or ship to other structure), capsize, sinking, breaking up, grounding, breakdown of the ship underway, stranding, and fire or explosion are mostly caused by human. ${ }^{17}$ Hence, this study is to be undertaken to discuss shipping accident in case study area, to determine indicators of human factors that influence shipping safety, to determine how much correlation and contribution between human factors and shipping safety.

\subsection{LITERATURE REVIEW}

\subsection{Human Factors}

The term used for human factors and human error always exchange in many industries without clearly defined. The terms are usually used for referring the cause of the accident that related to human. Human factors are scientific study of interaction between human and machine. ${ }^{14}$ Then it definition has expanded up to cover individual, group, and organization as a factor that might to effect safety. ${ }^{43}$ While Smallegange, et al. states that the Human Factors in Accidents at Sea as those accidents involving ships and their crew and cargo, which accidents are in some way linked to a human as opposed to a purely technical failure. ${ }^{35}$ 
There are three categories influencing human factors. ${ }^{43}$ They are individual factors, group factor, and organizational factors. Individual factor which includes competence level, stress, and motivation. Group Factors include: management weaknesses, supervision and crew factors. And organizational factors which include company policies, company standards, systems and procedures. A study by the Institute of Nuclear Power Operations showed that the underlying cause of at least $92 \%$ accidents in the nuclear industry is caused by human. It covered organizational, group and individual factors. ${ }^{21}$

\subsection{Shipping Safety}

According to Indonesia Marine Safety Coordination Agency, shipping safety is a condition that complies with several requirements regarding safety and security of transportation in water, port, and maritime environment. ${ }^{20}$ Shipping safety basically is all activities that exist and can be developed in relation to accident prevention activities in the shipping area. In Indonesia several requirements regarding to safety and security of transportation in water, port, and maritime environment regulated in Indonesia Law No.17 of 2008. Based on its Law, these requirements are:

I. Overall physical conditions of ship. They are construction, stability, electrical, and machinery while sailing.

II. Ships must be is equipped with a certificate and compliance document of ships while sailing.

III. Ships must be equipped with navigation equipment and/ or ship's electronic navigation that comply with requirements according to the type, size, and its shipping area.

iv. Ships must be equipped with radio communication device and its accessories that comply with requirements according to the type, size, and its shipping area.

v. Ships are fitted with metrology equipment that comply with requirements according to the type, size, and its shipping area.

VI. There are good information systems between ships and shipping information providers about the weather and sea conditions and its forecast.

vii. The ship is equipped with enough safety equipment (Life jackets, lifeboats, life raft, lifebuoy) according to the number of passengers and crew while it ship is sailing.

viii. Ships are equipped with adequate fire fighting equipment while it ship is sailing.

ix. Ships are equipped with an alarm signal that have well functioning when it ship is sailing.

x. Navigational equipment can help to improve safety and efficiency of navigation while it ship is sailing.

$\mathrm{Xi}$. Operation of telecommunications systems can help to improve shipping safety while it ship is sailing.

xii. Repair and maintenance are done periodically as an effort to increase of shipping safety.

xiii. Monitoring and checking to shipping safety requirements that be done by the competent authority is conducted as an effort to increase shipping safety.

Shipping safety have been also regulated by international agencies that managing and handling all matters related to the safety of life, sea properties, and sustainability of the marine environment. Its agency is called International Maritime Organization (IMO), which under the United Nations. One important factor in achieving the safety and sustainability of the marine environment is the human factors. It human factors related to managing, supervising, competence level, stress, and motivation of people. Because somehow solidness of construction of a ship and no matter how sophisticated the technology and good navigational equipment, without good human factor according to their function then it will be vain.

\subsection{Shipping Accidents}

Shipping accident is Shipping accident is a term generally used for any accident results in financial loss, either in life and/or property or both. ${ }^{1}$ The reasons for shipping accidents are many and complex. Increased sizes of ships to achieve economies in transportation costs are one of the primary reasons. Bigger size brings corresponding increases in cargo and passenger capacity; hence when an accident or a casualty occurs, the risk of life and property immediately becomes higher. Reduced shipping maneuverability in connection with larger scale, which ultimately is a function of increased risk, is another contributing factor in marine accidents. ${ }^{8}$

There are many types of shipping accidents and can effect to the environment around the ship, its property from the ship, and can effect to the people. Collision or contact (can be ship to ship or ship to other structures), capsize, sinking, breaking up, breakdown of the ship underway, stranding, and fire or explosion are examples of shipping accidents commonly. ${ }^{2}$

Based on investigation of the national transportation safety committee of Indonesia, there are 28 cases of ship accident was investigated from 2007 to 2011 with several types of ship accident (Figure 1). ${ }^{29}$

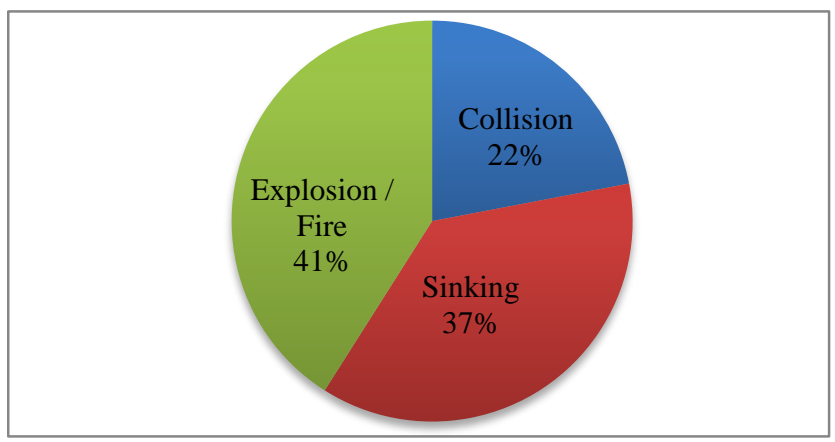

Figure 1 Percentage type of ship accident (National Transportation Safety Committee of Indonesia, 2011)

From time to time ships have the greater size. In economic scale it makes a benefit due to the more capacity for carrying goods and passengers. So when the accident happens, the risk is high. The possibility of losing property and life is enormous.

There are many factors that make accident happen. Generally can be classified as several factors. ${ }^{2}$

i. Natural conditions could be natural phenomena such as tidal stream, high wave, strong winds, restricted visibility due to fog, smoke, rain or snow, storm, etc.

ii. Technical failure such as lack of repair and maintenance, steering failure, engine failure, and structure failure as a result from lack of accurately ship design.

iii. Human factors are all of human factor which contribute accident happen both of organization, group, or individual factor.

According to Marine Safety Authority of New Zealand49\% of shipping incidents cited human factors as a cause, while only $35 \%$ cite technical factors and $16 \%$ environmental. ${ }^{24}$ The most common human factors causes were errors of judgment and improper lookout or watch keeping, followed by failure to comply with regulations. The 'human element' as it is often termed in the shipping has frequently been cited as a cause of these costly incidents. 


\subsection{METHODOLOGY}

Collecting data method of this research is by using a questionnaire. A questionnaire was made based on classification of human factors. Before questionnaire are distributed to get a real data. A questionnaire was tested to 30 respondents who are working at one shipping company (PT. Baruna Jaya) as passenger ship's crew to determine its validity and reliability by using Ms.Excel program. After the test is done, results show that 17 organizational factor statements, 11 group factor statements, 12 individual factor statements, and 10 shipping safety statements are valid with a reliability value for each variables are $0860,0.767$, 0721, and 0.8. By using its valid statements, questionnaires distributed to 86 respondents who are working as passenger ship's crew at two shipping companies (PT Baruna Jaya and PT. Lestari IndomaBahari). After obtaining data, analysis requirements test (normality, homogeneity, linearity and independence test between independent variables) needs to be done to determine the statistical method to be used. Correlation and regression method by using SPSS program was used to determine the contribution of human factors to shipping safety, either carried out independently between an independent variable to dependent variable, or together between three independent variables to the dependent variable.

\subsection{RESULT}

\subsection{Shipping Accident In Case Study Area}

Case study or Riau Archipelago province located on $04^{\circ} 15^{\prime}$ North Latitude - $0^{\circ} 45^{\prime}$ South Latitude and 103 $11^{\prime}$ - 109 $10^{\circ}$ ' East Longitude. ${ }^{16}$ It has 2.408 big and small islands. And the ratio between land area and water area is about $4 \%$ land area and $96 \%$ water area. ${ }^{16}$ The situation of a case study area can be seen in Figure 2 .

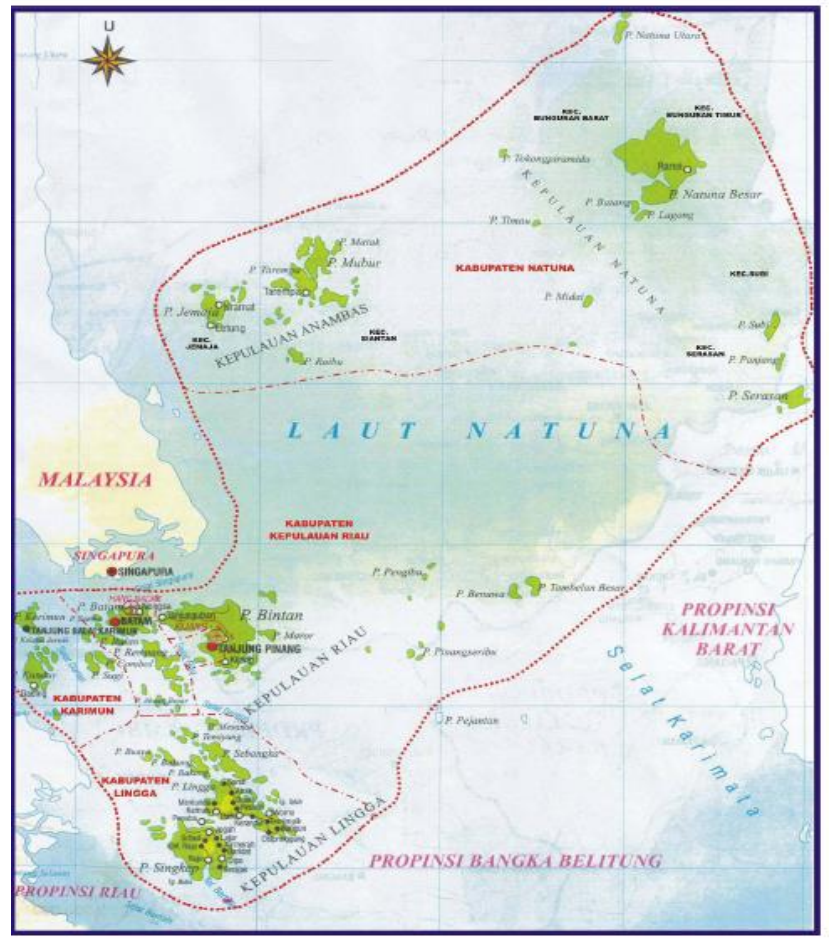

Figure 2 Case study area (Health Department of Riau archipelago Province 2006)
With wider water area than land area, make water transportation is a mainly transportation that be used in the case study area. Many ships through Riau Archipelago waters that serve national and international shipping. It caused shipping accident to always happen in this case study area. Based on report of the Search and Rescue agency of the Riau Archipelago Province, there are 22 cases of shipping accidents during the last two years in the case study area. It can be seen in following figure. ${ }^{34}$

From Figure 3 below can be seen there are 14 cases of ship sinking, 4 cases of ship grounding, 2 cases of ship explosion or fire, 1 case of ship capsizing, and 1 case of ship collision. So during the last two years shipping accident that frequently happens is sinking.

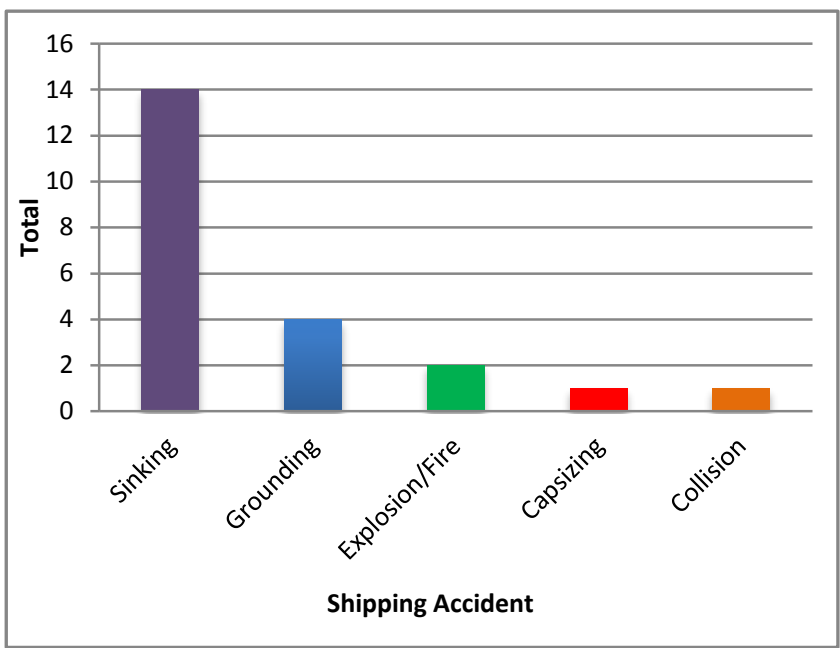

Figure 3 Shipping accident in case study area (Search and Rescue Agency of Riau Archipelago Province, 2012)

\subsection{Analysis Requirements Test}

Before starting to analyze data, analysis requirements test is needed. It is used to decide data analysis method will be used. These analysis requirements test are normality test, homogeneity test, linearity test between independent variables and dependent variable, and independence test between independent variables. If all of analysis requirements are filled, the analysis data method can be done by using parametric statistical formula.

\subsubsection{Normality Test}

The purpose of normality tests in this study is to view normal or abnormal a distribution of data. This test is done by using Kolmogorov - Seminov (K-S test). Significance level that be used as a basis to reject or accept the decision of normal or abnormal a data distribution (Alpha) is 0.05 . The hypothesis that be proposed for this normality test are as bellow:

$\mathrm{H} 0=$ Data is abnormal distribution

$\mathrm{H} 1=$ Data is the normal distribution

By using a basis of decision making if value of Asymp. Significance more than the value of significance level (0.05), H1 is accepted and if value of Asymp. Significance less than the value of significance level $(0.05), \mathrm{H} 1$ is rejected. The result of normality test shows value of Asymp. Sign for each independent variable and dependent variable are $0.092,0.108,0328$, and 0.114 . While the value of significance level that be used is 0.05 . Based on basis of its decision making above, $\mathrm{H} 1$ is accepted. This can be stated that all of variables in this study have normal data distribution. 


\subsubsection{Homogeneity Test}

Beside test of normality data, test of homogeneity data also needs to be done. It is intended to view data that be obtained from a homogeneous sample. Homogeneity test is very important if researchers will be generalizing the result of their study. A hypothesis that is proposed for this homogeneity test are as bellow:

$\mathrm{H} 0=$ Data distribution is not from homogeneous sample

$\mathrm{H} 1=$ Data distribution is from homogeneous sample

By using a basis of decision making if value of Asymp. Significance more than the value of significance level (0.05), H1 is accepted and if value of Asymp. Significance less than the value of significance level (0.05), H1 is rejected. The result of normality test are value of Asymp. Sign for each independent variable to dependent variable are $0.136,0.097$, and 0.131 . While the value of significance level that be used is 0.05 . Based on the basis of its decision making above, $\mathrm{H} 1$ is accepted. This can be stated that distribution data is from homogenous sample.

\subsubsection{Linearity Test}

Linearity test is a test that be done to view data distribution of each independent variable is from a linear line to the dependent variable. The hypothesis that be proposed for this linearity test are as bellow:

$\mathrm{H} 0=$ Data distribution of Independent variable is not form a linear line to the dependent variable

H1 = Data distribution of Independent variable is formed a linear line to the dependent variable

By using a basis of decision making if value of Asymp. Significance more than the value of significance level (0.05), H1 is accepted and if value of Asymp. Significance less than the value of significance level (0.05), H1 is rejected. The result of linearity test are value of Asymp. Sig (Deviation from linearity) for each independent variable to dependent variable are 0.413 , 0.535 , and 0.421 . While the value of significance level that be used is 0.05 . Based on the basis of its decision making above, $\mathrm{H} 1$ is accepted. This can be stated that Data distribution of Independent variable is from a linear line to the dependent variable.

\subsubsection{Independence Test between Independent Variables}

Independence test between independent variables is done to know there are any correlations between its three independent variables. If there is a large and significant correlation between its three independent variables, its mean its three independent variables are not independent. The result Independence test between independent variables are correlation between variable X1 and X2 is 0.041 and significance value is 0.79 . The correlation between variable $\mathrm{X} 1$ and $\mathrm{X} 3$ is 0.126 and significance value is 0.247 and the correlation between variable $\mathrm{X} 2$ and $\mathrm{X} 3$ is 0.125 and significance value is 0.093 . All of significance value is more than the value of significance level. Although it means there are correlation between three independent variables but it is not significant.

\subsection{Hyphothesis Test}

Hypothesis test is conducted by using the correlation method and linear regression analysis, either linear regression with one independent variable nor linear regression with some independent variables. These correlation method is used to know how far correlation between independent variables and a dependent variable. At the same time linear regression analysis is used to determine the contribution of independent variables to the dependent variable in a linear equation. ${ }^{40}$

There are two principal tests in linear regression analysis. The first one is linearity test and the second one is coefficient test. Linear regression analysis with some independent variable usually also requires autocorrelation test. The autocorrelation test indicates whether random or not a data. Autocorrelation is a coefficient that indicates a correlation between two values of the same variable on time horizon $\mathrm{xi}$ andxi+k. Autocorrelation can be conducted by using a Durbin Watson test. If the value of Durbin Watson less than 1.21 or more than 2.79 , its mean there is autocorrelation.

\subsubsection{First Hypothesis}

First hypothesis are shipping safety is contributed by organizational factors. The hypothesis that be proposed for this first hypothesis test are as bellow.

- $\quad \mathrm{HO}=$ Shipping safety is not contributed by organizational factors

- $\quad \mathrm{H} 1=$ Shipping safety is contributed by organizational factors

By using a basis of decision making if value of Asymp. Significantly more than the value of significance level (0.05), H0 is accepted and if value of Asymp. Significance less than the value of significance level (0.05), H0 is rejected. The result of the first hypothesis test is the correlation coefficient between organizational factor and shipping safety (rx1y) is 0.368 and its determination coefficient is 0.135 with significant value is 0.000 . (Less than significance alpha 0.05). it is indicated that the correlation between organizational factor variable (X1) and shipping safety (Y) correlate at confidence level $95 \%$.

Linear regression analysis with one variable independent is conducted to know the correlation between organizational factor variable (X1) and shipping safety (Y) predictive or not.

Based on calculation then obtain regression line equation is $\mathrm{Y}=29.807+0.235 \mathrm{X} 1$. The further analysis is a statistic test. It is intended to verify it line regression equation coefficient that there on organizational factor variable (X1) can be accepted as a predictor to identify this phenomena that take place, like shipping safety $(\mathrm{Y})$ is contributed by organizational factor (X1).

Based on its calculation can be known value of $t_{\text {calc }} \mathrm{X} 1$ variable is 3.65 , and table $(0.05 ; 85)$ is 1.988 with significance value 0.000 (less than significance alpha 0.05 ). It is indicated that the direction of regression line can be used as a predictor to view correlation and contribution between organizational factor (X1) and shipping safety (Y).

A further analysis is a regression equation test that formed to test the level of it's significance. This analysis test is conducted with $\mathrm{F}$ test. The result is value $\mathrm{F}_{\text {calcis }} 99.176$ and values of table $(0.05 ; 1: 85)$ is 3.9519 with significant value is 0.000 (less than significance alpha 0.05). It is indicated that regression equation models is formed $\mathrm{Y}=29.807+0.235 \mathrm{X} 1$ is linear and significant at confidence level $95 \%$.

Based on the analysis above can be concluded that shipping safety $(\mathrm{Y})$ is contributed by organizational factor (X1). Therefore the first hypothesis that state shipping safety (Y) is contributed by organizational factor (X1) have been tested empirically and can be accepted at confidence level $95 \%$. Contribution of organizational factor to shipping safety is $13.5 \%$.

\subsubsection{Second Hypothesis}

Second hypothesis are shipping safety is contributed by group factor. A hypothesis that is proposed for this first hypothesis test are as below: 
$\mathrm{H} 0=$ Shipping safety is not contributed by group factor

$\mathrm{H} 1$ = Shipping safety is contributed by group factor

By using a basis of decision making if value of Asymp. Significantly more than the value of significance level $(0.05), \mathrm{H} 0$ is accepted and if value of Asymp. Significance less than the value of significance level $(0.05), \mathrm{H} 0$ is rejected. The result of the second hypothesis test is the correlation coefficient between group factor and shipping safety (rx2y) is 0.243 and its determination coefficient is 0.059 with significant value is 0.002 . (less than significance alpha 0.05). It is indicated that the correlation between group factor variable (X2) and shipping safety (Y) correlate at confidence level $95 \%$.

Linear regression analysis with one variable independent is conducted to know the correlation between group factor variable (X2) and shipping safety (Y) predictive or not. Based on calculation then obtain regression line equation is $\mathrm{Y}=39.2726+$ $0.284 \mathrm{X} 2$. The next analysis is a statistic test. It is intended to verify it line regression equation coefficient that there on group factor variable (X2) can be accepted as a predictor to identify this phenomena that take place, like shipping safety $(\mathrm{Y})$ is contributed by group factor (X2).

Based on its calculation can be known value of $t_{\text {calc }} \mathrm{X} 2$ variable is 2.4 , and $t_{\text {table }}(0.05 ; 85)$ is 1.988 with significance value 0.002 (less than significance alpha 0.05). It is indicated that the direction of regression line can be used as a predictor to view correlation and contribution between group factor (X2) and shipping safety (Y).

A further analysis is a regression equation test that formed to test the level of it's significance. This analysis test is conducted with $F$ test. The result are value $F_{\text {calc }}$ is 14.626 and value of $\mathrm{F}_{\text {table }}(0.05 ; 1: 85)$ is 3.9519 with significant value is 0.002 (less than significance alpha 0.05). it is indicated that regression equation models is formed $\mathrm{Y}=39.2726+0.284 \mathrm{X} 2$ is linear and significant at confidence level $95 \%$.

Based on the analysis above can be concluded that shipping safety $(\mathrm{Y})$ is contributed by group factor (X2). Therefore second hypothesis that states shipping safety $(\mathrm{Y})$ is contributed by group factor (X2) have been tested empirically and can be accepted at confidence level $95 \%$. Contribution of group factor to shipping safety is $5.9 \%$.

\subsubsection{Third Hypothesis}

Third hyphotesis is shipping safety is contributed by individual factors. The hypothesis that be proposed for this first hypothesis test are as bellow:

$\mathrm{HO}=$ Shipping safety is not contributed by individual factors

$\mathrm{H} 1$ = Shipping safety is contributed by individual factors

By using a basis of decision making if value of Asymp. Significantly more than the value of significance level (0.05), H0 is accepted and if value of Asymp. Significance less than the value of significance level (0.05), H0 is rejected. The result of the first hypothesis test is the correlation coefficient between individual factor and shipping safety $(\mathrm{rX} 3 \mathrm{y})$ is 0.243 and its determination coefficient is 0.059 with significant value is 0.002 . (less than significance alpha 0.05). it is indicated that the correlation between individual factor variable (X3) and shipping safety (Y) correlate at confidence level $95 \%$.

Linear regression analysis with one variable independent is conducted to know the correlation between individual factor variable (X3) and shipping safety (Y) predictive or not. Based on calculation then obtain regression line equation is $\mathrm{Y}=38.214+$ $0.196 \mathrm{X} 3$. The next analysis is a t statistic test. It is intended to verify it line regression equation coefficient that there are on individual factor variable (X3) can be accepted as a predictor to identify this phenomena that take place, like shipping safety $(\mathrm{Y})$ is contributed by individual factor (X3).

Based on its calculation can be known value of tcalc $\mathrm{X} 3$ variable is 2.14 , and table $(0.05 ; 85)$ is 1.988 with significance value 0.019 (less than significance alpha 0.05). It is indicated that the direction of regression line can be used as a predictor to view correlation and contribution between individual factor (X3) and shipping safety (Y).

A further analysis is a regression equation test that formed to test the level of it's significance. These analytical tests are conducted with $F$ test. The result are value $F_{\text {calc }}$ is 26.51 and value of $F_{\text {table }}(0.05 ; 1: 85)$ is 3.9519 with significant value is 0.0019 (less than significance alpha 0.05). It is indicated that regression equation models is formed $\mathrm{Y}=38.214+0.196 \mathrm{X} 3$ is linear and significant at confidence level $95 \%$.

Based on the analysis above can be concluded that shipping safety (Y) is contributed by individual factor (X3). Therefore the third hypothesis that states shipping safety $(\mathrm{Y})$ is contributed by an individual factor (X3) have been tested empirically and can be accepted at confidence level $95 \%$. The contribution of individual factor to shipping safety is $17.4 \%$.

\subsubsection{Fourth Hypothesis}

Fourth hypothesis are shipping safety is contributed together by organizational factor, group factor, and individual factor. The hypothesis that be proposed for this first hypothesis test are as bellow:

$\mathrm{H} 0=$ Shipping safety is not contributed together by human factors $\mathrm{H} 1$ = Shipping safety is contributed together by human factors

By using a basis of decision making if value of Asymp. Significantly more than the value of significance level (0.05), H0 is accepted and if value of Asymp. Significance less than the value of significance level (0.05), H0 is rejected. The result of the fourth hypothesis test is the correlation coefficient between individual factor and shipping safety $(\mathrm{rx} 1 \times 2 \times 3 \mathrm{y})$ is 0.448 and its determination coefficient is 0.0288 with significant value is 0.000 . (less than significance alpha 0.05). It is indicated that the correlation between three independent variables $(\mathrm{X} 1, \mathrm{X} 2, \mathrm{X} 3)$ and shipping safety (Y) correlate at confidence level $95 \%$ and the value of Durbin Watson more than 2.79 , its mean there is autocorrelation.

Multiple linear regression analysis with three variable independent is conducted to know the correlation between organizational factor (X1), group factor (X2), individual factor variable (X3) and shipping safety (Y) are predictive or not.

Based on calculation then obtain regression line equation is $\mathrm{Y}=34.459+0.263 \mathrm{X} 1+0.396 \mathrm{X} 2+0.583 \mathrm{X} 3$. The next analysis is a t statistic test. It is intended to verify it line regression equation coefficient that there on organizational factor variable (X1), group factor variable (X2), and individual factor variable (X3) can be accepted as a predictor to identify this phenomena that take place, like Shipping safety (Y) is contributed together by an organizational factor (X1), group factor (X2), and individual factor (X3).

Based on its calculation can be known value of $t_{\text {calc }}$ for $\mathrm{X} 1$ variable is 4.168 , $\mathrm{t}_{\text {calc }} \mathrm{X} 2$ for variable is 3.322 , $\mathrm{t}_{\text {calc }}$ for $\mathrm{X} 3$ variable is 5.584 and $t_{\text {table }}(0.05 ; 85)$ is 1.988 with three significance valuations (X1. X2, and X3) are $0.000,0.002$, and 0.019 (less than significance alpha 0.05). It is indicated that the direction of regression line can be used as a predictor to view correlation and contribution together between organizational factor (X1), group factor (X2), individual factor (X3), and shipping safety (Y).

A further analysis is a regression equation test that formed to test the level of it's significance. These analytical tests are conducted with $\mathrm{F}$ test. The result is value Fcalc is 38.419 and 
value of table $(0.05 ; 3: 81)$ is 2.7173 with significant value is 0.000 (less than significance alpha 0.05). it is indicated that regression equation models is formed $\mathrm{Y}=34.459+0.263 \mathrm{X} 1+0.396 \mathrm{X} 2+$ $0.583 \mathrm{X} 3$ is linear and significant at confidence level $95 \%$.

Based on the analysis above can be concluded that shipping safety $(\mathrm{Y})$ is contributed together by an organizational factor $(\mathrm{X} 1)$, group factor $(\mathrm{X} 2)$, and individual factor (X3). Therefore the fourth hypothesis that state shipping safety $(\mathrm{Y})$ is contributed together by an organizational factor (X1), group factor (X2), and individual factor (X3) has been tested empirically and can be accepted at confidence level 95\%. Contribution between three independent variables (human factors) to shipping safety is $28.8 \%$.

\subsection{DISCUSSION}

According to Indonesia Marine Safety Coordination Agency (2009), shipping safety is a condition that complies with several requirements regarding safety and security of transportation in water, port, and maritime environment. Shipping safety basically is all activities that exist and can be developed in relation to accident prevention activities in the shipping area. In Indonesia several requirements regarding to safety and security of transportation in water, port, and maritime environment regulated in Indonesia Law No.17 of 2008.

One important factor in achieving the safety and sustainability of the marine environment is the human factors. Its human factors related to managing, supervising, competence level, stress, and motivation of people. But in reality the human factor is the biggest factor that contributes shipping accident like collision or contact (can be ship to ship or ship to other structures), capsize, sinking, breaking up, breakdown of the ship underway, stranding, and fire or explosion. As has been mentioned by Marine Safety Authority of New Zealand (1996) $49 \%$ of shipping incidents cited human factors as a cause, while only $35 \%$ cite technical factors and $16 \%$ environmental while in Indonesia $39.3 \%$ shipping accident is caused by human factors and $60.7 \%$ shipping accident is caused by technical factor. ${ }^{24}$

Based on result of the above, the validity of the hypothesis test show that all of the hypothesis $\mathrm{H} 1$ in this study can be accepted, either independently test of each other nor taken together. Its mean from simple regression analysis and multiple regression analysis, prove that there are contribution of organizational factor, group factor, and individual factor either the test is independent of each other nor taken together for shipping safety.

Analysis result from the first hypothesis proves that shipping safety is contributed by organizational factors. The obtained finding from data analysis is show that the correlation between organizational factor and shipping safety is 0.365 and the closeness of relationship between its two variables is 0.135 . It means that the $13.5 \%$ organizational factor is contribute shipping safety. Then analysis result from second hypothesis also proves shipping safety is contributed by group factor. The obtained finding from data analysis is show that the correlation between group factor and shipping safety is 0.243 and the closeness of relationship between its two variables is 0.059 . It means that just $5.9 \%$ group factor is contribute shipping safety. And then the third hypothesis test proves that shipping safety is also contributed by individual factors. The obtained finding from data analysis is show that the correlation between individual factor and shipping safety is 0.418 and the closeness of relationship between its two variables is 0.174 . It means that the $17.4 \%$ individual factor is contribute shipping safety. When the hypothesis test is carried out together between three independent variables to dependent variable show that correlation between three independent variables and shipping safety is 0.488 with closeness of relationship is 0.288 . Its means $28 \%$ shipping safety are contributed by human factors. While $71.2 \%$ are thought to have originated from other factors that not studied in this study.

As an element of shipping safety, human factors have an important role in an effort to provide a cleaner and safer in its operation. But accidents frequently happen due to human factors. The high number of shipping accidents due to human factors is caused by a lower contribution of human factors to shipping safety. As mention in above only $28.8 \%$ shipping safety is contributed by human factors.

In shipping accident that caused by human factors, human behavior and performance and also safety culture can be the prevailing factors that prescribe the level of safety for numerous maritime transport procedures and practices of management. ${ }^{11}$ This means that they can also influence, in a considerable degree, the protection of the marine and coastal environment. Thus, a flexible way to reduce the frequency and severity of naval accidents is, by identifying the contributing factors to the socalled human error, and by investigating for methods, which will either eliminate or mitigate these mistakes.

Other causes of lower contribution of human factors to shipping safety maybe also comes from Lack of concern for shipping safety of all parties include shipping company, ship's owner, government, regulatory authorities, classification society and other parties also be causes of lower contribution of human factors to shipping safety. However the solidness construction of the ship and no matter how sophisticated the technology and good navigational equipment, without good human factor according to their function then it will be vain.

\subsection{CONCLUSION AND RECOMMENDATION}

\subsection{Conclusion}

Based on the results of the study presently undertaken, the following conclusions can be made:

i. There are 22 cases of shipping accidents during the last two years in the case study area. 14 cases of ship sinking, 4 cases of ship grounding, 2 cases of ship explosion or fire, 1 case of ship capsizing, and 1 case of ship collision. So during the last two years shipping accident that frequently happens is sinking.

ii. There are three categories of human factors. They are individual factor which includes competence level, stress, and motivation. Group Factor which includes supervision, and crew factors. And organizational factor which includes company policies, company standards, systems and procedures. ${ }^{14}$

iii. The correlation between organizational factor and shipping safety is 0.365 and contributions of organizational factor to shipping safety is $13.5 \%$ While the correlation between group factor and shipping safety is 0.243 and contributions of group factor to shipping safety is $5.9 \%$. Then the correlation between individual factor and shipping safety is 0.418 and contributions of individual factor to shipping safety is $17.4 \%$. And the last one correlation between three independent variables and shipping safety is 0.488 with contribution of three independent variables to shipping safety is $28 \%$.

\subsection{Recommendation}

The present work has successfully shown the contribution of human factors to shipping safety. However, there are some 
shortcomings in this study. Therefore some suggestions for further research and improvement are shown here:

i. All parties which involve in shipping like to include shipping company, ship's owner, government; regulatory authorities, classification society and other parties should take a serious concern about safety in shipping.

ii. This study only focuses on the contribution of human factors to shipping safety without a look at their safety culture, human behavior, and their adopted regulation on safety operation, safety management, crew requirements, etc.

iii. Correlation and regression method is used to determine the contribution of human factors to shipping safety on this study by using software SPSS without doing a comparison with other software.

iv. Qualitative method approaches have limitations, especially in the preparation of the questionnaire. Considering to questionnaire statements have been prepared based on the theory which its study is limited so there are some other aspects that have not been represented and not measurable.

\section{References}

[1] N. Akten. 1982. Turkish Maritime Accident. Maritime Accidents in Turkey Symposium. Istanbul: Insurance Law Association.

[2] N. Akten. 2006. Shipping Accidents: A Serious Threat for Marine Environment. J. Black Sea/Mediterranean Environment. 12: 269-204.

[3] S. Arikunto 1996. ProsedurPenelitian. Edisi III. Jakarta: PT. Rineka Citra.

[4] D. Ary, L. C. Jacobs and A. Razavieh. 2009. Introduction to Reasearch in Education. $8^{\text {th }}$ ed. Wardsworth: USA.

[5] C.Baldick. 2008. Oxford Dictionary of Literary Terms. 3th edition. New York: Oxford University Press.

[6] M.T.Baysari, S.Andrew, McIntosh, and J. R. Wilson. 2008 Understanding The Human Factors Contribution to Railway Accidents and Incidents in Australia. Accident Analysis and Prevention. 40: 17501757

[7] M. Celik, and S. Cebib. 2009. Analytical HFACS for Investigating Human Errors in Shipping Accidents. Accident Analysis and Prevention. 41: 66-75.

[8] S. E. Chapman, and N. Akten. 1998. Marine Casualties in the Turkish Straits- a Way Ahead, Seaways. The Nautical Institute, London. 6-8, ISSN 0144-1019.

[9] S. L. Chin,and L. T. Chaur. 2008. The Effects of Safety Climate on Vessel Accidents in The Container Shipping Context. Accident Analysis and Prevention. 40: 594-601.

[10] Chin, Shan Lu and Chung, Shan Yang. 2011. Safety Climate and Safety Behavior in the Passenger Ferry Context. Accident Analysis and Prevention. 43: 329-341.

[11] X, M. De Oses, and N.P. Ventikos. 2005. A Critical Assessment of Human Element Regarding Maritime Safety: Issues of Planning, Policy and Practice.

[12] I. Donald, and D. Canter. 1994. Employee Attitudes and Safety in the Chemical Industry. Journal of Loss Prevention in the Process Industries. 7(3).

[13] C. S. Fugas, A. Silvia, B. Silva, L. Jose, and Meliac. 2011. Another Look at Safety Climate and Safety Behavior: Deepening The Cognitive and Social Mediator Mechanisms. Accident Analysis and Prevention. 45: 468-477.

[14] P. E. R. Gordon. 1996. The Contribution of Human Factor to the Accidents in the Offshore Oil Industry. Reliability Engineering and System Safety. 61(1998): 95-108.

[15] R. Gordon, R. Flin, and K. Mearns. 2005. Designing and Evaluating a Human Factors Investigation Tool (HFIT) for Accident Analysis. Safety
Science. 43: 147-171. Gove, P. B. 2002. Webster's 3rd New International Dictionary of the English Language.USA: Merriam Inc.

[16] Health Department of Riau Archipelago Province. 2006. Profil Kesehatan Provinsi Kepulauan Riau 2006, Tanjung Pinang.

[17] H. W. Heinrich, D. Peterson, and N. Roos. 1980. Industrial Accident Prevention. McGrawHill, New York.

[18] C. Hetherington, R. Flin, and K. Mearns. 2006. Safety in Shipping: The Human Element. Safety Reasearch. 37: 401-404.

[19] Indonesia. 2008. Pelayaran. 17

[20] Indonesia Marine Safety Coordination Agency.2009. Kebijakan Keselamatan dan Keamanan Transportasi Laut. Badan Koordinasi Keamanan Laut: Jakarta.

[21] Institute of Nuclear Power Operations. 1985. An Analysis of Root Causes in 1983 Significant Event Reports. Atlanta. 85-027.

[22] A. Irianto.1998. Statistik Konsep Dasar \& Aplikasinya, Jakarta: Prenada Media Group.

[23] G. Luria. 2010. The Social Aspects of Safety Management: Trust and Safety Climate. Accident Analysis and Prevention. 42: 1288-1295.

[24] Maritime Safety Authority of New Zealand (1995-1996). Maritime Accidents. New Zealand.

[25] Ministry of Marine Affairs and Fisheries. 2012. Transportasi laut Indonesia Miliki Peran Penting dalam Pembangunan Nasional. Seminar PeranTransportasiLaut di Negara Kepulauan. March 2012. Jakarta: Ministry of Marine Affairs and Fisheries.

[26] Ministry of Marine Affairs and Fisheries. 2012. Transportasi Laut Indonesia Miliki Peran Penting dalam Pembangunan Nasional. Seminar Peran Transportasi Laut di Negara Kepulauan. March 2012. Jakarta: Ministry of Marine Affairs and Fisheries.

[27] Ministry of Transportation. 2000. Orasi Ilmiah pada Dies Natalis XXX STMT Trisakti. April 2000. Jakarta.

[28] I. Nathanael. 2011. Safety Analysis on Crew of Ship Based on Concept of Marine Labour Convention (MLC) 2006 in Passenger Ship. Sepuluh Nopember Institute of Technology: Undergraduate Thesis.

[29] National Transportation Safety Committee of Indonesia. 2011. Analisis Data Kecelakaan dan Investigasi

[30] Transportasi LautTahun 2007-2011. Konferensi Pers Akhir Tahun 2011. Desember 2011. Jakarta: Ministry of Transportation.

[31] E. Olsen. 2010. Exploring the Possibility of a Common Structural Model Measuring Associations Between Safety Climate Factors and Safety Behavior in Health Care and the Petroleum Sectors. Accident Analysis and Prevention. 42: 1507-1516.

[32] J. M. Patterson, A. Scott, and Shappell. 2010. Operator Error and System Deficiencies: Analysis of 508 Mining Incidents and Accidents from Queensland, Australia Using HFACS. Accident Analysis and Prevention. 42: 1379-1385.

[33] J. Reason. 1991. Human Error. University Press: Cambridge.

[34] Search and Rescue Agency of Riau Archipelago Province. 2012. Report of Disaster on Aviation, Shipping, Natural Disaster and Other Disaster. Not Published.

[35] V. Smallegange. Dam, and V. Derstelt. 2001. The Human Factor in Accidents at Sea. Conference Mare Forum. 29th-30th October 2001.

[36] N. Sudjana. 1982. Analisi Regresi. Jakarta: Sera Jaya.

[37] H. Suewedo. 2009. Environment and Transportation Safety. Quality Management. 8(2): 133-140.

[38] Sugiyono. 2002. Metode Penelitian Administrasi. Edisi I. Bandung: CV. Alfabeta.

[39] Transportation Department of Riau Archipelago Province. 2012. Tanjung Pinang Working Area Passenger Ship Fleet Data. Transportation Department of Riau Archipelago Province.

[40] C. Trihendradi. 2011. Langkah Mudah Melakukan Analisis Statistik Menggunakan SPSS 19. $1^{\text {st }}$ ed. Andi:Yogyakarta.

[41] B. Tuckman. 1972. Conducting Educational Research. New York: Harcourt Brace Jovanovich, Inc.

[42] U. Varonen and M. Mattila. 2000. The Safety Climate and Its Relationship to Safety Practices, Safety of theWork Environment and Occupational Accidents in Eight Wood-processing Companies. Accident Analysis and Prevention. 32: 761-769.

[43) B. Wilpert. 1995. Psychology in High Hazard Systems-Contributions to Safety and Reliability. Invited Keynote Address given at the IV European Congress of Psychology. July 1995. Athens. 